\title{
Development of Machinable High-Strength Copper-Based Alloys by Sulfide Dispersion*1
}

\author{
Katsunari Oikawa ${ }^{1}$, Hiroharu $\operatorname{Ido}^{2}$, Hajime Mitsui ${ }^{2} * 2$ and Kiyohito Ishida ${ }^{2}$ \\ ${ }^{1}$ National Institute of Advanced Industrial Science and Technology, Tohoku Center, Sendai 983-8551, Japan \\ ${ }^{2}$ Department of Materials Science, Graduate School of Engineering, Tohoku University, Sendai 980-8579, Japan
}

\begin{abstract}
Studies on the properties of $\mathrm{Cu}-\mathrm{S}-\mathrm{Ti}$ and $\mathrm{Cu}-\mathrm{S}-\mathrm{Zr}$ alloys containing $0.8-1.6$ at $\% \mathrm{~S}$, and $0.4-2.7$ at $\%$ Ti or $\mathrm{Zr}$ were carried out. Titanium and zirconium formed $(\mathrm{Ti}, \mathrm{Cu}) \mathrm{S}$ and $(\mathrm{Cu}, \mathrm{Zr})_{2} \mathrm{~S}$, respectively, which were uniformly dispersed. Age-hardening phenomena were observed in the alloys having the composition ratio of $\mathrm{Ti} / \mathrm{S}>1$ or $\mathrm{Zr} / \mathrm{S}>1$, which indicates that the soluble titanium and zirconium in the $\mathrm{Cu}-\mathrm{matrix}$ after formation of sulfide result in age-hardening. ( $\mathrm{Ti}, \mathrm{Cu}) \mathrm{S}$ and $(\mathrm{Cu}, \mathrm{Zr})_{2} \mathrm{~S}$ were found to be the effective inclusions for improving the machinability. The $\mathrm{Cu}-\mathrm{S}-\mathrm{Ti}$ and $\mathrm{Cu}-\mathrm{S}-\mathrm{Zr}$ alloys developed by sulfide dispersion are very promising as a new type of copper-based alloys having high strength, high electrical conductivity and good machinability.
\end{abstract}

(Received July 7, 2003; Accepted August 21, 2003)

Keywords: titanium sulfide, zirconium sulfide, machinability, electrical conductivity, high strength

\section{Introduction}

The recent progress of electronic devices requires the miniaturization of components, such as switches, connectors and springs. Therefore, copper alloys as comprising materials of those electronic components must have not only high strength and high electrical conductivity but also high workability, such as bending strength, punching-ability and machinability.

It is well known that the microstructural control of fine inclusions improves punching-ability and machinability. In particular, a small amount of lead has long been used as an additive in steels, aluminum and brass, because lead is the most effective element for improving the machinability of these materials by minimizing the damage to other properties. However, it has become necessary to replace lead with nontoxic materials, because the potential of lead leaching into water from industrial scrap is known to be a health hazard. Sulfide inclusion is expected to be a promising candidate for improving the machinability of alloys. In the case of the steels, MnS inclusion is aggressively utilized for improving the machinability. In copper-based alloys, the free-cutting copper alloy adding sulfur to pure copper is known. ${ }^{1)}$ However, there have generally been very few attempts to utilize sulfides for microstructure control of copper-based alloys because $\mathrm{Cu}_{2} \mathrm{~S}$ formed in the alloys causes hot shortness ${ }^{2)}$ and discoloration. ${ }^{3)}$

The present work is one of a series of systematic studies $^{4-11)}$ on the phase equilibria and morphology of various sulfides in metals focusing on the formation of sulfide in $\mathrm{Cu}-\mathrm{Ti}^{12,13)}$ and $\mathrm{Cu}-\mathrm{Zr}^{14,15}$ ) high strength copper alloys showing an age-hardening effect. Ti sulfide and $\mathrm{Zr}$ sulfide in copper alloy are expected to be chemically and thermodynamically stable. ${ }^{16,17)}$ The microstructure, mechanical properties, electrical conductivity and machinability of copper-based alloys with varying $\mathrm{Ti}, \mathrm{Zr}$ and $\mathrm{S}$ contents were investigated to develop new machinable high strength $\mathrm{Cu}-\mathrm{S}$ -

\footnotetext{
${ }^{* 1}$ This Paper was Originally Published in Japanese in Journal of JRICu. 41 (2002) 186

${ }^{* 2}$ Graduate Student of Tohoku University
}

$\mathrm{Ti}$ and $\mathrm{Cu}-\mathrm{S}-\mathrm{Zr}$ alloys using both precipitation hardening and the $\mathrm{Ti}$ and $\mathrm{Zr}$ sulfide inclusions.

\section{Experimental}

\subsection{Sample preparations}

Alloy ingots weighing about $250 \mathrm{~g}$ each were prepared from oxygen-free copper, sponge titanium, sponge zirconium and $\mathrm{Cu}_{2} \mathrm{~S}$ powder by induction melting in magnesia crucibles under an argon atmosphere. The copper was melted first, and then alloying elements were added to the molten copper in order of titanium or zirconium and $\mathrm{Cu}_{2} \mathrm{~S}$. After the addition of $\mathrm{Cu}_{2} \mathrm{~S}$, the bath was kept in the molten state for 5 minutes and then poured into a permanent mold with a diameter of $20 \mathrm{~mm}$.

The ingots were hot-rolled to a thickness of $5 \mathrm{~mm}$ at 1073 K. Small specimens were cut from the sheet and sealed in quartz capsules with argon. The $\mathrm{Cu}-\mathrm{S}-\mathrm{Ti}$ and $\mathrm{Cu}-\mathrm{S}-\mathrm{Zr}$ specimens were annealed at $1273 \mathrm{~K}$ and $1173 \mathrm{~K}$ for 20 minutes, respectively, and then quenched in ice water. They were then cold-rolled to a thickness of $1 \mathrm{~mm}$ and sealed in evacuated quartz capsules. The specimens were aged at 573$873 \mathrm{~K}$ for 1 hour and then quenched in ice water.

Two different sulfur content series of alloys were prepared. Sulfur compositions of sulfur-lean and sulfur-rich alloys are 0.8 at $\%$ and 1.6 at $\%$, respectively. Ti and $\mathrm{Zr}$ contents were designed as the atomic ratio of $\mathrm{Ti} / \mathrm{S}$ or $\mathrm{Zr} / \mathrm{S}$ to be about 0.5 , $1,1.7$ and 2.6. Nominal composition of specimens are $\mathrm{Cu}-$ 0.8 at $\% \mathrm{~S}-(0.4,0.8,1.4,2.1)$ at $\% \mathrm{Ti}, \mathrm{Cu}-1.6$ at $\% \mathrm{~S}-(1.6,2.7)$ at $\% \mathrm{Ti}, \mathrm{Cu}-0.8$ at $\% \mathrm{~S}-(0.8,1.4)$ at $\% \mathrm{Zr}$ and $\mathrm{Cu}-1.6$ at $\% \mathrm{~S}-(0.8$, $1.6,2.7)$ at $\%$ Zr. The chemical analysis of alloy composition has not been conducted. However, the results of average chemical composition of alloys measured by an area analysis of a scanning electron microscope equipped with an energy dispersive X-ray micro-analyzer (SEM-EDX) well agreed with the nominal composition.

\subsection{Sample tests}

Micro Vickers hardness was measured on the surface of polished specimens under the condition of loading of $200 \mathrm{~g}$ for 15 seconds. The hardness was obtained as the average of 
10 measurement points. A tensile test was carried out under the condition of a cross-head speed of $0.5 \mathrm{~mm} / \mathrm{min}$. Electrical conductivity was measured by the eddy current method and was indicated by the international annealed copper standard unit, \%IACS. Examination of microstructure was carried out using a SEM-EDX. The surfaces of mirror-polished sections to be examined by SEM-EDX were etched electrolytically in a 5 mass $\%$ sodium citrate- $0.3 \mathrm{~N}$ sulfuric acid solution. Composition analysis of sulfide electrically extracted by a carbon replica method was carried out by a transmission electron microscope equipped with an energy dispersive Xray micro-analyzer (TEM-EDX). Machinability was evaluated in the drilling test. The drilling tool used was of TiNcoated high-speed steel (HSS) which was $6 \mathrm{~mm}$ in diameter, $130 \mathrm{~mm}$ in length and $135^{\circ}$ in point angle. The appearance of chips of the worked materials was observed.

\section{Results and Discussion}

\subsection{Microstructure}

Figure 1 shows the microstructure of the $\mathrm{Cu}-0.8 \% \mathrm{~S}$ $0.8 \% \mathrm{Ti}$ and $\mathrm{Cu}-0.8 \% \mathrm{~S}-0.8 \% \mathrm{Zr}$ alloys after hot-rolling. Fine precipitates smaller than $1 \mu \mathrm{m}$ in diameter are uniformly dispersed in both specimens. A similar microstructure was observed in other alloys. The composition analysis of precipitates in the extracted carbon replica specimens by TEM-EDX revealed that $(\mathrm{Ti}, \mathrm{Cu}) \mathrm{S}$ containing a small amount of $\mathrm{Cu}$ is formed in the $\mathrm{Cu}-0.8 \% \mathrm{~S}-0.8 \% \mathrm{Ti}$ alloy, as well as $(\mathrm{Cu}, \mathrm{Ti})_{2} \mathrm{~S}$ containing a small amount of $\mathrm{Ti}$. ( $\left.\mathrm{Ti}, \mathrm{Cu}\right) \mathrm{S}$ is a major precipitate in the $\mathrm{Cu}-0.8 \% \mathrm{~S}-0.8 \% \mathrm{Ti}$ alloy. On the other hand, $(\mathrm{Cu}, \mathrm{Zr})_{2} \mathrm{~S}$ containing a slight amount of $\mathrm{Zr}$ and $\mathrm{Cu}_{9} \mathrm{Zr}_{2}$ compound was observed in the $\mathrm{Cu}-0.8 \% \mathrm{~S}-0.8 \% \mathrm{Zr}$ alloy. In
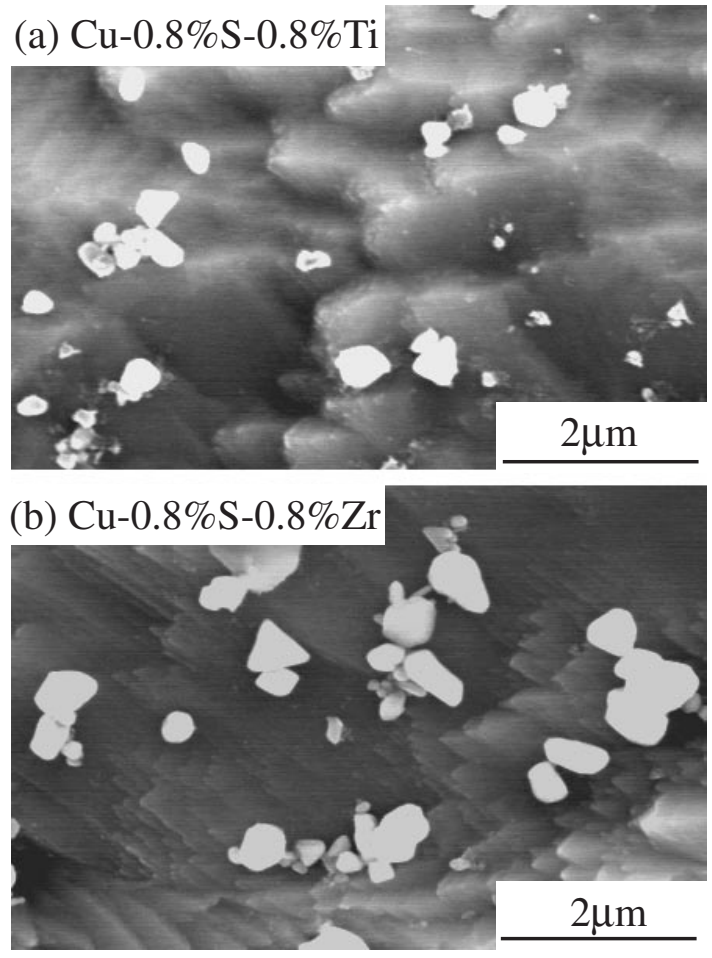

Fig. 1 Micrographs of (a) $\mathrm{Cu}-0.8 \% \mathrm{~S}-0.8 \% \mathrm{Ti}$ and (b) $\mathrm{Cu}-0.8 \% \mathrm{~S}-0.8 \% \mathrm{Zr}$ alloys.

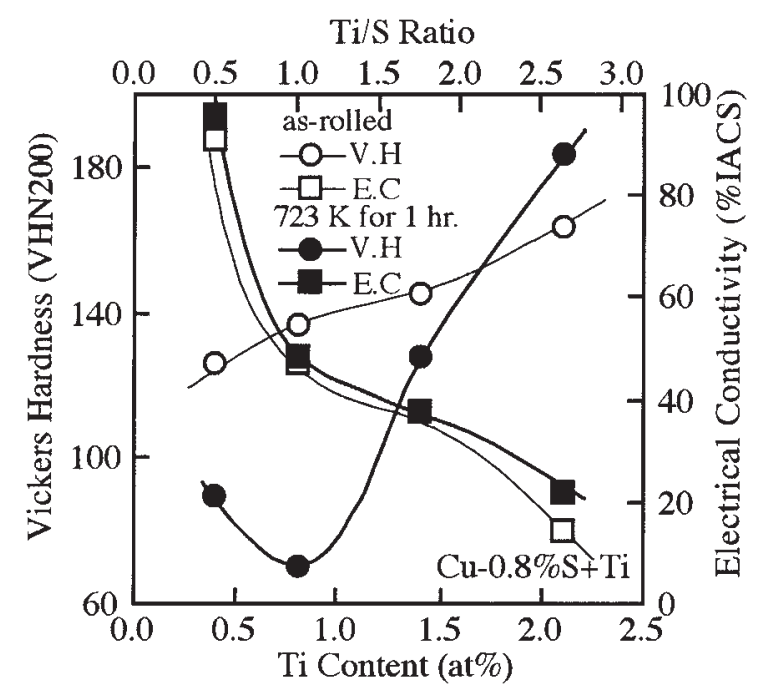

Fig. 2 Variation of hardness (V. H.) and electrical conductivity (E. C.) of the $\mathrm{Cu}-0.8 \% \mathrm{~S}-\mathrm{Ti}$ alloys with $\mathrm{Ti}$ content.

addition, a small amount of $\mathrm{MgS}$ was observed due to contamination from the crucible.

\subsection{Effect of the addition of $\mathrm{Ti}$ and $\mathrm{Zr}$}

Figure 2 shows Vickers hardness and electrical conductivity of as-rolled $\mathrm{Cu}-0.8 \% \mathrm{~S}-\mathrm{Ti}$ alloys as a function of $\mathrm{Ti}$ content. The hardness and electrical conductivity of the asrolled samples increase and decrease with increasing $\mathrm{Ti}$ content, respectively. In the samples aged at $723 \mathrm{~K}$ for 1 hour, the electrical conductivity monotonously decreases with increasing Ti content, while the hardness shows the minimum at about $0.8 \% \mathrm{Ti}$, where the atomic ratio of $\mathrm{Ti}$ and $\mathrm{S}$ contents is equal. The electrical conductivity of the aged samples is higher than those of the as-rolled samples, while the hardness of aged samples is lower and higher than those of the asrolled samples less than $1.5 \% \mathrm{Ti}$ and above $2.0 \% \mathrm{Ti}$, respectively.

Vickers hardness and electrical conductivity as a function of $\mathrm{Zr}$ content in the $\mathrm{Cu}-0.8 \% \mathrm{~S}-\mathrm{Zr}$ alloys are shown in Fig. 3. The hardness and electrical conductivity of both the as-rolled and aged specimens increase and decrease with increasing $\mathrm{Zr}$ content, respectively. The electrical conductivity tends to increase by aging at $673 \mathrm{~K}$ for 1 hour. On the other hand, the hardness of the aged specimens is lowered and raised when the atomic ratio of $\mathrm{Zr}$ and $\mathrm{S}$ contents, $\mathrm{Zr} / \mathrm{S}$, is below and above 1 , respectively.

The increase in the hardness by aging in the high $\mathrm{Ti}$ or $\mathrm{Zr}$ containing alloys is considered to be the result of the precipitation-hardening observed in the $\mathrm{Cu}-\mathrm{Ti}^{12,13)}$ and $\mathrm{Cu}$ $\mathrm{Zr}^{14,15)}$ alloys. Namely, $\mathrm{Ti}$ and $\mathrm{Zr}$ atoms added to the $\mathrm{Cu}-$ $0.8 \% \mathrm{~S}$ alloy form sulfides by reacting with $\mathrm{S}$ atom and do not contribute to age-hardening when the amount of $\mathrm{Ti}$ or $\mathrm{Zr}$ is small. With increasing $\mathrm{Ti}$ and $\mathrm{Zr}$ content, excess $\mathrm{Ti}$ and $\mathrm{Zr}$ atoms, which do not form sulfide, are considered to contribute to the precipitation hardening with aging.

\subsection{Effect of aging temperature}

Figure 4 shows the effect of the aging temperature on the Vickers hardness and electrical conductivity in the $\mathrm{Cu}-\mathrm{S}-\mathrm{Ti}$ 


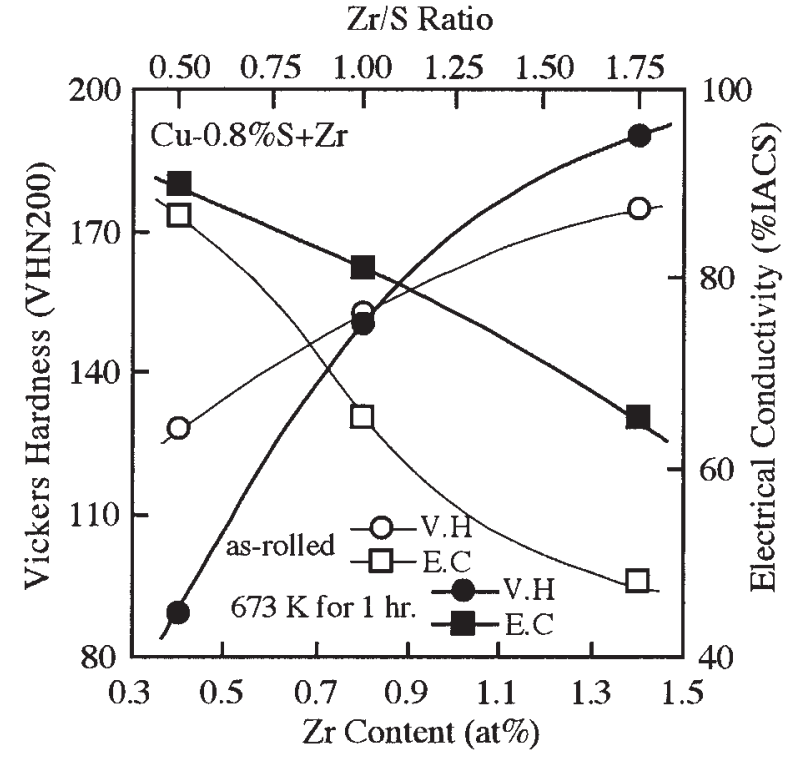

Fig. 3 Variation of hardness (V. H.) and electrical conductivity (E. C.) of the $\mathrm{Cu}-0.8 \% \mathrm{~S}-\mathrm{Zr}$ alloys with $\mathrm{Zr}$ content.

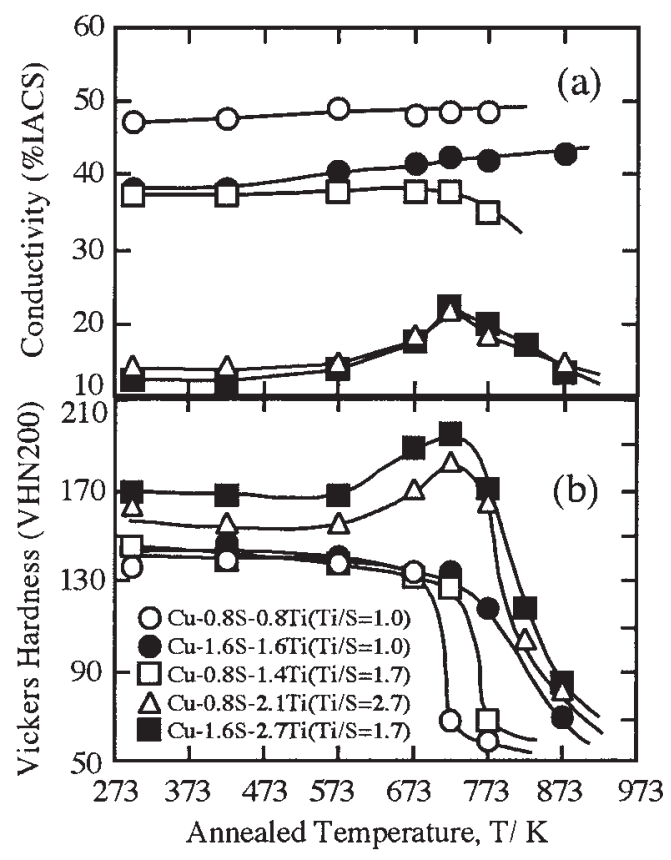

Fig. 4 Effect of aging temperature on (a) hardness and (b) electrical conductivity of the $\mathrm{Cu}-\mathrm{S}-\mathrm{Ti}$ alloys, where aging time is 1 hour.

alloys. The electrical conductivity increases slightly and the hardness is remarkably softened by aging above $673 \mathrm{~K}$ in the alloys containing $\mathrm{Ti}$ and $\mathrm{S}$ at an atomic ratio of $\mathrm{Ti} / \mathrm{S}=1$. The alloys containing $\mathrm{Ti}$ and $\mathrm{S}$ at a ratio of $\mathrm{Ti} / \mathrm{S}<1$ show almost the same behavior. The hardness and electrical conductivity of the $\mathrm{Cu}-0.8 \% \mathrm{~S}-2.1 \% \mathrm{Ti}(\mathrm{Ti} / \mathrm{S}=2.7)$ and $\mathrm{Cu}-1.6 \% \mathrm{~S}-2.7 \% \mathrm{Ti}$ $(\mathrm{Ti} / \mathrm{S}=1.7)$ alloys increase with increasing aging temperature, and show the maximum peaks at $723 \mathrm{~K}$. Further elevation of aging temperature remarkably reduces both the hardness and electrical conductivity. On the other hand, in the $\mathrm{Cu}-0.8 \% \mathrm{~S}-1.4 \% \mathrm{Ti}$ alloy $(\mathrm{Ti} / \mathrm{S}=1.7)$, the electrical conductivity does not show remarkable change due to the aging temperature, and the hardness decreases above $723 \mathrm{~K}$.

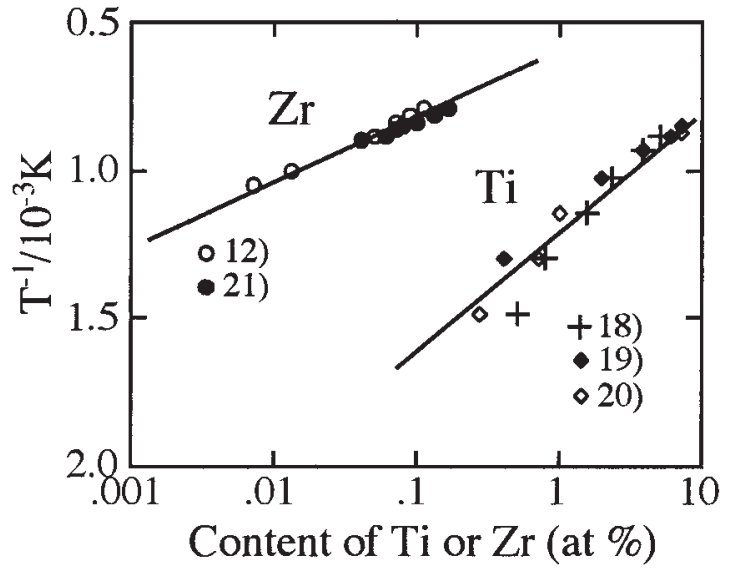

Fig. 5 Solubility limit of $\mathrm{Ti}$ and $\mathrm{Zr}$ on the $\mathrm{Cu}-\mathrm{fcc}$ phase. ${ }^{11,18-20)}$

Both the $\mathrm{Cu}-1.6 \% \mathrm{~S}-2.7 \% \mathrm{Ti}$ and $\mathrm{Cu}-0.8 \% \mathrm{~S}-1.4 \% \mathrm{Ti}$ alloys contain $\mathrm{Ti}$ and $\mathrm{S}$ at a ratio of $\mathrm{Ti} / \mathrm{S}=1.7$. The former shows age-hardening but the latter does not. The age-hardening is caused by precipitation of solute $\mathrm{Ti}$ atoms in the $\mathrm{Cu}-\mathrm{fcc}$ phase. Hence, the evaluation of the effective Ti content, $C_{\mathrm{Ti}}^{\text {eff }}$, which does not form sulfide, is more useful in the discussion of age-hardening rather than $\mathrm{Ti} / \mathrm{S}$ ratio. It is difficult to obtain the exact value of $C_{\mathrm{Ti}}^{\text {eff }}$ because sulfide is formed as (Ti, $\left.\mathrm{Cu}\right) \mathrm{S}$. Here the formation of the ideal stoichiometry compound, TiS, is assumed, namely the value of $C_{\mathrm{Ti}}^{\mathrm{eff}}$ is evaluated by the total Ti content minus the total sulfur content. The amount of $C_{\mathrm{Ti}}^{\text {eff }}$ in the $\mathrm{Cu}-0.8 \% \mathrm{~S}-1.4 \% \mathrm{Ti}, \mathrm{Cu}-0.8 \% \mathrm{~S}-2.1 \% \mathrm{Ti}$ and $\mathrm{Cu}-$ $1.6 \% \mathrm{~S}-2.7 \% \mathrm{Ti}$ alloys is calculated as $0.6 \%, 1.3 \%$ and $1.1 \%$, respectively. The solubility limit of $\mathrm{Ti}$ in the $\mathrm{Cu}-\mathrm{fcc}$ phase is shown in Fig. 5 $^{18-20)}$ The solubility limit of $\mathrm{Ti}$ in the $\mathrm{Cu}-\mathrm{fcc}$ phase is about 3.0 at $\% \mathrm{Ti}$ at $1273 \mathrm{~K}$, namely, the $C_{\mathrm{Ti}}^{\mathrm{eff}}$ of the $\mathrm{Cu}-0.8 \% \mathrm{~S}-1.4 \% \mathrm{Ti}, \mathrm{Cu}-0.8 \% \mathrm{~S}-2.1 \% \mathrm{Ti}$ and $\mathrm{Cu}-1.6 \% \mathrm{~S}-$ $2.7 \% \mathrm{Ti}$ alloys is able to completely dissolve in the matrix at $1273 \mathrm{~K}$, while only $0.5 \% \mathrm{Ti}$ can dissolve in the matrix at $723 \mathrm{~K}$, which is the temperature showing the maximum of age-hardening in the $\mathrm{Cu}-0.8 \% \mathrm{~S}-2.1 \% \mathrm{Ti}$ and $\mathrm{Cu}-1.6 \% \mathrm{~S}-$ $2.7 \% \mathrm{Ti}$ alloys. Therefore, the age-hardening is caused by the precipitation of the $\mathrm{Cu}_{4} \mathrm{Ti}$ phase formed from solute $\mathrm{Ti}$ atoms of $C_{\mathrm{Ti}}^{\mathrm{eff}}$ (about $1 \%$ ) and their electrical conductivity increases with a decrease in the solute $\mathrm{Ti}$ in the matrix. The reason why the softening and reduction of electrical conductivity simultaneously occur above $773 \mathrm{~K}$ is the recrystallization and decrease of the precipitation of the $\mathrm{Cu}_{4} \mathrm{Ti}$ phase resulting from the increase of the solubility limit of Ti with increasing aging temperature. The hardness and electrical conductivity in the $\mathrm{Cu}-0.8 \% \mathrm{~S}-2.1 \% \mathrm{Ti}$ alloy after solution-treatment are $72.35 \mathrm{VHN}$ and $14.5 \%$ IACS, respectively, which is similar to those of the specimen aged at $873 \mathrm{~K}$. Furthermore, the solubility limit of $\mathrm{Ti}$ at $873 \mathrm{~K}$ is about $1 \%$, as shown in Fig. 5. These facts suggest that $\mathrm{Ti}$ atoms of $C_{\mathrm{Ti}}^{\mathrm{eff}}$ in the $\mathrm{Cu}-0.8 \% \mathrm{~S}-2.1 \% \mathrm{Ti}$ and $\mathrm{Cu}-1.6 \% \mathrm{~S}-$ $2.7 \% \mathrm{Ti}$ alloys hardly precipitate as the $\mathrm{Cu}_{4} \mathrm{Ti}$ phase by aging above $873 \mathrm{~K}$. In the same way, the value of $C_{\mathrm{Ti}}^{\text {eff }}$ of the $\mathrm{Cu}-$ $0.8 \% \mathrm{~S}-1.4 \% \mathrm{Ti}$ alloy is comparable to the solubility limit of $\mathrm{Ti}$ in the matrix at $723 \mathrm{~K}$. Hence, the $\mathrm{Cu}_{4} \mathrm{Ti}$ phase is hardly precipitated by aging at $723 \mathrm{~K}$ and the age-hardening is not clearly shown.

Figure 6 shows the effect of the aging temperature on the 

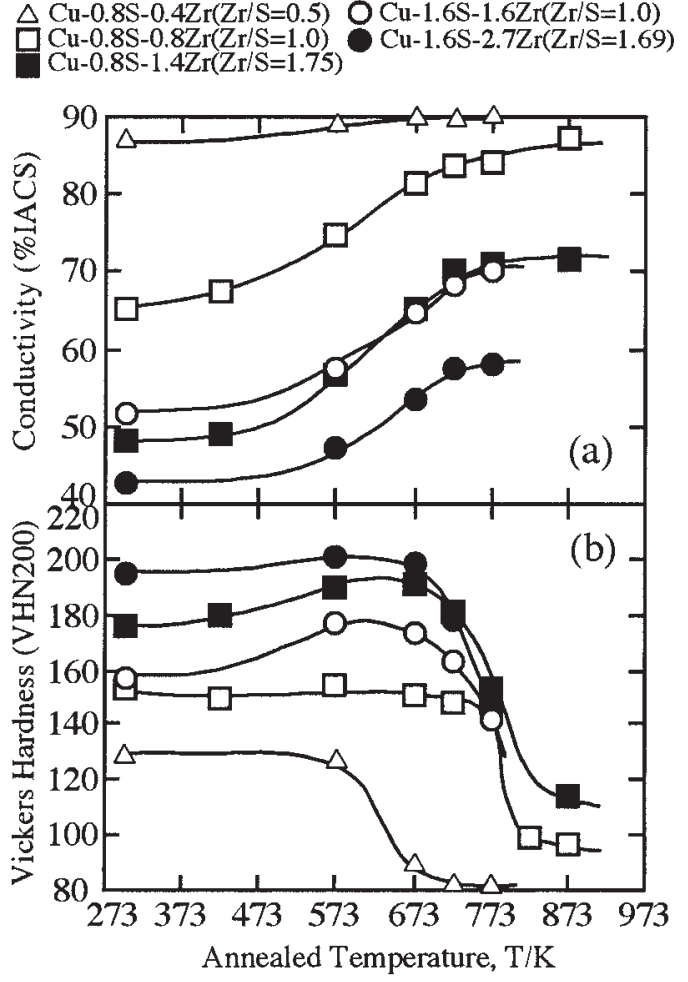

Fig. 6 Effect of aging temperature on (a) hardness and (b) electrical conductivity of the $\mathrm{Cu}-\mathrm{S}-\mathrm{Zr}$ alloys, where aging time is 1 hour.

Vickers hardness and electrical conductivity in the $\mathrm{Cu}-\mathrm{Zr}-\mathrm{S}$ alloys. The electrical conductivity of the $\mathrm{Cu}-0.8 \% \mathrm{~S}-0.4 \% \mathrm{Zr}$ alloy $(\mathrm{Zr} / \mathrm{S}=0.5)$ slightly increases with increasing aging temperature and the hardness drastically decreases above $673 \mathrm{~K}$. On the other hand, the alloys containing $\mathrm{Zr}$ and $\mathrm{S}$ at a ratio of $\mathrm{Zr} / \mathrm{S}>1$ show slight age-hardening and tend to increase the electrical conductivity. Since the $(\mathrm{Cu}, \mathrm{Zr})_{2} \mathrm{~S}$ and $\mathrm{Cu}_{9} \mathrm{Zr}_{2}$ phases are formed at solution treatment in the $\mathrm{Zr}$-rich alloys, the effective $\mathrm{Zr}$ content, $C_{\mathrm{Zr}}^{\mathrm{eff}}$, which can be soluble in the $\mathrm{Cu}$-matrix, is difficult to estimate. The solubility limit of $\mathrm{Zr}$ in the $\mathrm{Cu}$-matrix as shown in Fig. $5^{12,21)}$ is two orders of magnitude smaller than that of Ti. In addition, it is known that the $\mathrm{Cu}-\mathrm{Zr}$ alloys show age-hardening by precipitation of the $\mathrm{Cu}_{5} \mathrm{Zr}$ phase, even if a small amount of $\mathrm{Zr}$, namely, about $0.01 \%$, is added. ${ }^{14)}$ Further investigations are necessary to permit detailed discussion of the relation between $C_{\mathrm{Zr}}^{\mathrm{eff}}$ and age-hardening.

In the $\mathrm{Cu}-\mathrm{S}-\mathrm{Zr}$ alloys, the electrical conductivity increases by aging above $773 \mathrm{~K}$, although the hardness drastically decreases. The electrical conductivity in the $\mathrm{Cu}-0.8 \% \mathrm{~S}$ $1.4 \% \mathrm{Zr}$ alloy $(\mathrm{Zr} / \mathrm{S}=1.7)$ aged at $873 \mathrm{~K}$ for 1 hour is $71.7 \%$ IACS, which is higher than $56.3 \%$ IACS of the solutiontreated specimen. Since the existence of solute $\mathrm{Zr}$ in the $\mathrm{Cu}-$ matrix drastically decrease the electrical conductivity, ${ }^{15)}$ the precipitation of $\mathrm{Cu}_{9} \mathrm{Zr}_{2}$ and the solute $\mathrm{Zr}$ content in the $\mathrm{Cu}$ matrix increase and decrease with increasing aging temperature, respectively. The softening at aging above $773 \mathrm{~K}$ is due to the coarsening of the precipitation by overaging. This tendency agrees with the previous results for $\mathrm{Cu}-\mathrm{Zr}$ alloys. $^{13,14)}$

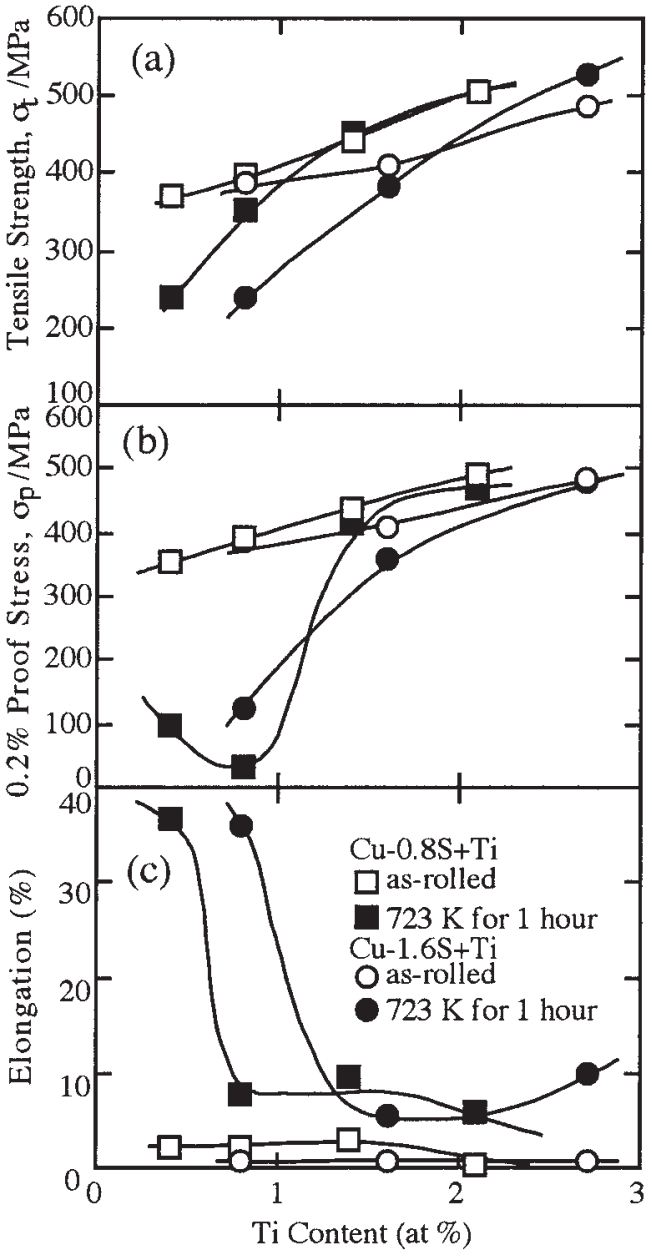

Fig. 7 Mechanical properties of the tensile test of $\mathrm{Cu}-\mathrm{S}-\mathrm{Ti}$ alloys as a function of Ti content. (a) tensile strength, (b) $0.2 \%$ proof stress and (c) elongation.

\subsection{Tensile test}

Figure 7 shows the characteristic properties obtained by the tensile test for the $\mathrm{Cu}-\mathrm{S}$-Ti alloys as-rolled and aged at $723 \mathrm{~K}$ for 1 hour as a function of Ti content. The tensile strength and $0.2 \%$ proof stress of as-rolled samples increase with increasing Ti content while the elongation is evenly low. For the aged samples, the tensile strength and $0.2 \%$ proof stress tend to increase with increasing $\mathrm{Ti}$ content. The elongation of the low Ti content alloys is remarkably high, while that of the alloys containing $\mathrm{Ti}$ above $1 \%$ is almost constant. The tensile strength and $0.2 \%$ proof stress of the aged specimens decrease while the elongation increases compared with the as-rolled specimens containing $\mathrm{Ti}$ and $\mathrm{S}$ at a ratio of $\mathrm{Ti} / \mathrm{S}<1$. For the specimens containing $\mathrm{Ti}$ and $\mathrm{S}$ at a ratio of $\mathrm{Ti} / \mathrm{S}>1$ showing age-hardening, the tensile strength and $0.2 \%$ proof stress of the aged specimens hardly change, although the elongation increases.

The results of the tensile test for the $\mathrm{Cu}-\mathrm{S}-\mathrm{Zr}$ alloys asrolled and aged at $723 \mathrm{~K}$ for 1 hour are as shown in Fig. 8. The tendency is almost same as that of the $\mathrm{Cu}-\mathrm{S}-\mathrm{Ti}$ alloys.

The relation between the electrical conductivity and tensile strength in the present $\mathrm{Cu}-\mathrm{S}-\mathrm{Ti}$ and $\mathrm{Cu}-\mathrm{S}-\mathrm{Zr}$ alloys is compared with that of some commercial copper-based alloys as shown in Fig. 9. It is known that there is a trade-off relation between strength and electrical conductivity. The alloys with 


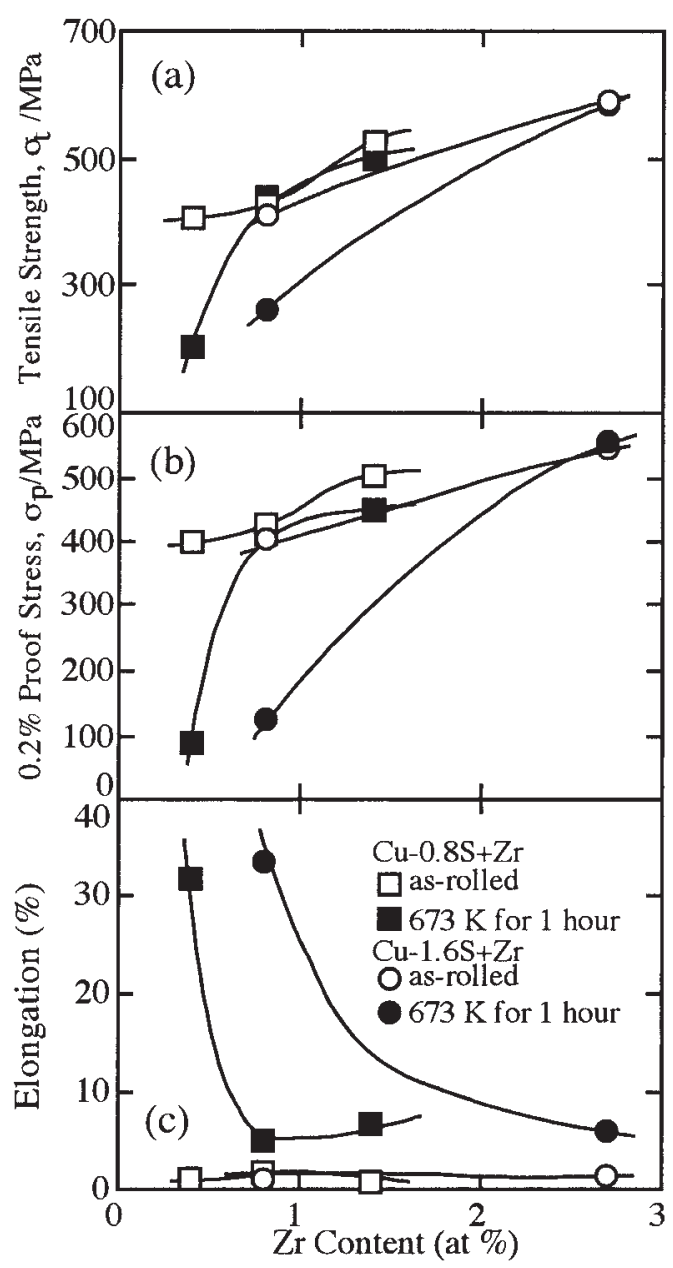

Fig. 8 Mechanical properties of the tensile test of $\mathrm{Cu}-\mathrm{S}-\mathrm{Zr}$ alloys as a function of $\mathrm{Zr}$ content. (a) tensile strength, (b) $0.2 \%$ proof stress and (c) elongation.

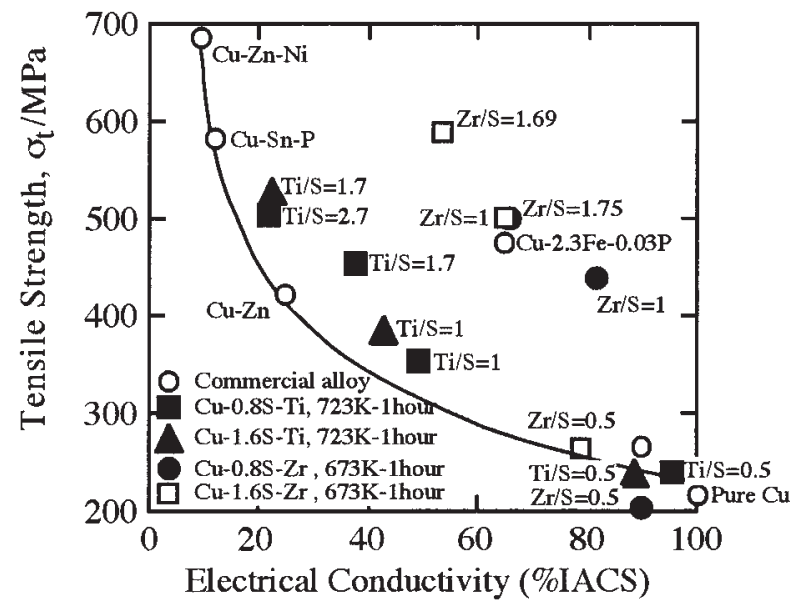

Fig. 9 Tensile strength versus electrical conductivity of $\mathrm{Cu}-\mathrm{S}-\mathrm{Ti}$ and $\mathrm{Cu}-\mathrm{S}$ $\mathrm{Zr}$ alloys aged at $673 \mathrm{~K}$ for 1 hour and corresponding values of some commercial copper-based alloys.

both $\mathrm{Ti} / \mathrm{S}>1$ and $\mathrm{Zr} / \mathrm{S}>1$ show high strength and, particularly, $\mathrm{Cu}-\mathrm{S}-\mathrm{Zr}$ alloys have higher electrical conductivity than $\mathrm{Cu}-\mathrm{S}-\mathrm{Ti}$ alloys with the same level of strength. For example, the tensile strength and electrical conductivity of the $\mathrm{Cu}-1.6 \% \mathrm{~S}-2.7 \% \mathrm{Zr}$ alloy are $588 \mathrm{MPa}$ and $58.1 \%$ IACS,
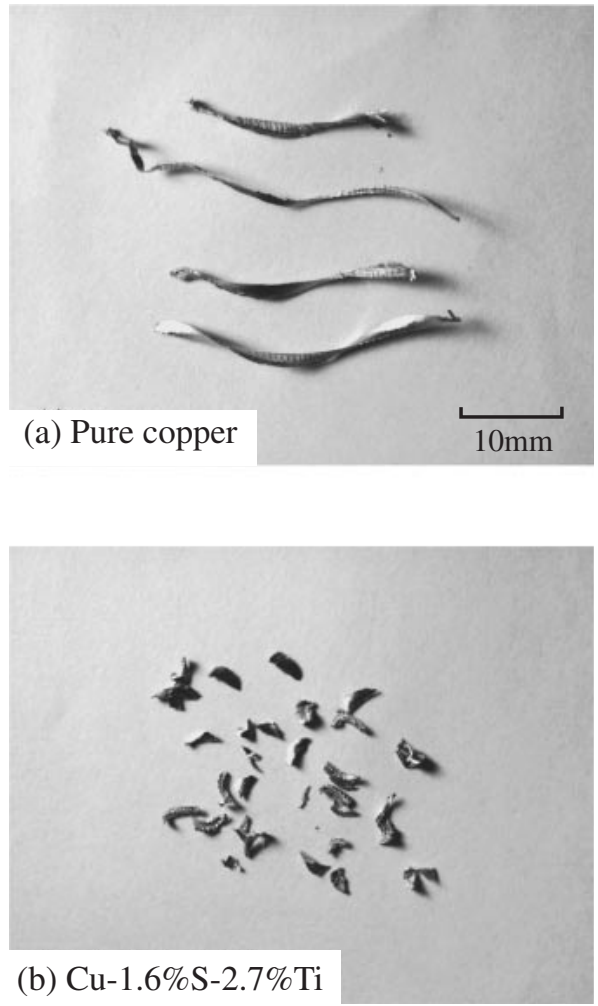

Fig. 10 Appearance of the chips of worked materials by drill testing of pure copper and $\mathrm{Cu}-2.7 \% \mathrm{Ti}-1.6 \% \mathrm{~S}$ alloys.

respectively. Furthermore, the softening temperature is above $673 \mathrm{~K}$ as shown in Figs. 4 and 5, and those alloys have the same or better heat resistance than commercial copper-based alloys.

\subsection{Machinability}

Figure 10 shows the appearance of the chips of the worked pure copper and $\mathrm{Cu}-1.6 \% \mathrm{~S}-2.7 \% \mathrm{Ti}$ alloy by the drilling test. The breakability of the chips of the $\mathrm{Cu}-1.6 \% \mathrm{~S}-2.7 \% \mathrm{Ti}$ alloy is better than that of pure copper. All of the developed alloys have better breakability of chips than pure copper. It is considered that the sulfide inclusion acts as a nucleate for cracking chips by stress concentration. Further investigations involving detailed tests of the machinability of these alloys are necessary in the future.

\section{Conclusion}

Microstructure, mechanical properties, electrical conductivity and machinability of sulfide-dispersed $\mathrm{Cu}-\mathrm{S}$-Ti and $\mathrm{Cu}-$ $\mathrm{S}-\mathrm{Zr}$ alloys with 0.8-1.6 at\% $\mathrm{S}$ and 0.4-2.7 at\% Ti and $\mathrm{Zr}$ were investigated. The results obtained are as follows:

(1) The alloys containing $\mathrm{Ti}, \mathrm{Zr}$ and $\mathrm{S}$ at ratios of $\mathrm{Ti} / \mathrm{S}>1$ and $\mathrm{Zr} / \mathrm{S}>1$ show age-hardening when the effective $\mathrm{Ti}$ and $\mathrm{Zr}$ contents in the matrix corresponding to the solubility before aging, $C_{\mathrm{Ti}}^{\text {eff }}$ and $C_{\mathrm{Zr}}^{\mathrm{eff}}$, are high. Furthermore, the electrical conductivity increases by age-precipitation due to the decrease of solute $\mathrm{Ti}$ and $\mathrm{Zr}$ contents in the $\mathrm{Cu}-\mathrm{fcc}$ matrix.

(2) The tensile strength tends to increase with increasing $C_{\mathrm{Ti}}^{\mathrm{eff}}$ and $C_{\mathrm{Zr}}^{\mathrm{eff}}$. 
(3) The property of breaking chips at drill-working is remarkably improved by dispersed sulfide inclusions in the $\mathrm{Cu}-\mathrm{Ti}-\mathrm{S}$ and $\mathrm{Cu}-\mathrm{Zr}-\mathrm{S}$ alloys.

(4) $\mathrm{Cu}-\mathrm{S}-\mathrm{Ti}$ and $\mathrm{Cu}-\mathrm{S}-\mathrm{Zr}$ alloys with dispersed $(\mathrm{Ti}, \mathrm{Cu}) \mathrm{S}$ and $(\mathrm{Cu}, \mathrm{Zr})_{2} \mathrm{~S}$ are promising as a new type of copperbased alloys having high strength, high electrical conductivity and better heat resistance and machinability.

\section{REFERENCES}

1) Metals Handbook, Nonferrous Alloys and Special-purpose Materials, vol. 2, 10th ed., (ASM international OH, 1990) pp. 216.

2) M. Kanno and N. Shimohira: J. JRICu. 27 (1988) 35-44.

3) T. Koizumi, S. Huruya, T. Toshiaki and Y. Maeda: J. JRICu 16 (1977) 98-104.

4) K. Oikawa, N. Kawashita, H. Ohtani, K. Ishida and T. Nishizawa: J. Jpn. Inst. Met. 59 (1995) 1207-1214

5) K. Oikawa, H. Ohtani, K. Ishida and T. Nishizawa: ISIJ Int. 35 (1995) 402-408.

6) K. Oikawa, K. Ishida and T. Nishizawa: ISIJ Int. 37 (1997) 332-338.

7) K. Oikawa, S.-I. Sumi and K. Ishida: Z. Metallkd. 90 (1999) 13-18.
8) Y. Ohuchi, K. Oikawa, I. Ohnuma and K. Ishida: Mater. Sci. Forum. 284-2 (1998) 509-516.

9) K. Oikawa, S.-I. Sumi and K. Ishida: J. Phase Equilib. 20 (1999) 215221.

10) H. Ohtani, K. Oikawa and K. Ishida: High Temp. Mater. Processing 19 (2000) 197-210.

11) K. Oikawa, H. Mitsui, T. Ebata, T. Takiguchi, T. Shimizu, K. Ishikawa, T. Noda, M. Okabe and K. Ishida: ISIJ Int. 42 (2002) 806-807.

12) M. J. Saaririrta and H. S. Cannon: Metals Prog. 76 (1959) 81.

13) S. Nagarjuna, K. Balasubramanian and D. S. Sarma: Mater. Trans., JIM 36 (1995) 1058-1066.

14) M. J. Saarivirta: Trans. AIME 218 (1960) 43-4371.

15) D. Zhilli, A. Sekiya, W. Fujitani and S. Hori: J. Jpn. Inst. Met. 53 (1989) 672-677.

16) H. Kaneko, T. Nishizawa and K. Tamaki: J. Jpn. Inst. Met. 24 (1960) 837-841.

17) O. Knake, O. Kubashewski and H. Hesselman: Thermochemical Properties of Inorganic Substances, (Springer-Verlag, 1991) pp. 2100.

18) E. Raub, P. Walter and M. Engel: Z. Metallkd. 43 (1952) 112-118.

19) U. Zwicker: Z. Metallkd. 53 (1962) 709-714.

20) K. Nagata and S. Nishikawa: Rep. Inst. Ind. Sci. Univ. Tokyo 29 (1981) 99-138.

21) W. Showak: Metall. Soc. AIME. 224 (1962) 1297-1298. 